\title{
RELATIONSHIP BETWEEN THE BIG FIVE PERSONALITY FACTOR WITH ENVIRONMENTAL INSIGHTS RELATED TO GREEN ARCHITECTURE
}

\author{
Hakim and Tri Endangsih \\ Universitas Budi Luhur, Indonesia. \\ hakim@budiluhur.ac.id
}

\begin{abstract}
The purpose of this study is to provide information and find out the relationship between conscientiousness with environmental insight behavior. The method used is a survey method with correlational techniques. This research is concerned with collecting data to determine whether there is a relationship between variables and how much strength the relationship has (correlation coefficient). The sampling technique in this study uses simple random sampling. the results showed that environmentally friendly behavior will increase if the big five personality factors (conscientiousness, agreeableness, neuroticism, openness and extraversion) are also increased. Factors to improve the behavior of environmental insights related to green architecture are the Policy implication as an effort to increase openness, Theoritical implication and Research implication.
\end{abstract}

Keywords: The Big Five Personality Factor, Conscientiousness, Environmentally Friendly Behavior

\section{INTRODUCTION}

Today, public awareness of the achievement of better environmental performance is carried out in controlling environmental impacts in producing and providing services to the organization in a manner consistent with the regulations and objectives of the organization. The ability of organizations to manage environmental performance is a strategic issue for many organizations in the world, because the environment today is an asset to provide organizational value. Goh, et.al., (2006: 118-123) said, the consequence is that managers are not only preoccupied by reducing working hours, improving quality and reducing costs, but have great concern for environmental issues[1]. So the environment is part of the assets for the organization's value, so it needs to be taken into account by the leadership in addition to reducing work hours, quality and cost.

This is consistent with the results of research by Sawitria, et.al., (2014: 27-33) that with the development of insights on the harmful effects of lifestyles practiced in modern society on the environment, changes in the behavior of environmental insights have become the main focus not only of environmental policy but also applied in environmental psychology[2]. So a theoretical framework that is needed to understand the development of environmental insight related to green architecture. Understanding environmental insight behavior related to green architecture is very important because it will contribute to the development of theories related to management of environmental insight behavior related to green architecture and to inform policy makers when designing to encourage environmental insight behavior related to green architecture.

Budi Luhur University is a place where students are educated and matured in order to provide solutions to a nation's problems. Therefore, a university should be at the forefront in solving a nation's problems, including environmental problems such as waste, wasteful use of water and electricity by inducing the concept of green architecture. The realization of an environmentally friendly campus is a real action to answer various environmental problems that occur. Green architecture can be interpreted as an architecture that consumes minimal natural resources, including energy, water, and materials, and minimizes negative environmental impacts[3]. The application of green architecture will provide a great opportunity for human life in a sustainable manner. Green architecture applications will create a sustainable form of architecture.

The purpose of this study is to obtain information on whether there is a relationship between conscientiousness, agreeableness, neuroticism, openness, and extraversion both individually or together with environmental insight related to green architecture. Based on several references of previous research novelty (novelty) of this study on the behavior of environmental insights related to green architecture and the big five personality factor (conscientiousness, agreeableness, neuroticism, openness, and extraversion).

\section{THEORITICAL FRAMEWORK}

In principle, the behavior of environmental insight related to green architecture is related to how one's personality. This is based on research conducted by Robertson and Barling (2013: 176-194), showing that greening institutions through transformational leadership influence pro employee environmental behavior[4]. Furthermore, research by Chamorro-Premuzio, Snelgar and Furnham (2015), shows that the personality of "The 
Big Five Personality" influences three domains of one's environmental care attitude namely biocentric, egocentric, and anthropocentric / altruistic[5].

Research by Liao, Ho, and Yang (2016: 51-71), says that the influence of the media contributes directly and indirectly to the effects of the media on attitudes, social norms, and pro-environment behavior[6]. The greatest influence of the media on behavioral intentions. While attitudes, descriptive, and subjective norms have a smaller effect. So someone will behave in an environmental insight related to greater green architecture, if preceded by an intention to be environmentally friendly. While the influence of attitudes, descriptions, and subjective norms is behind the intention to conduct environmental insight related to green architecture.

Research by Gifford and Nilsson (2014: 1-17), reviewed personal and social influences on caring and behavioral insight into the environment. Personal factors include childhood experiences, knowledge and education, personality and self-construal, sense of control, values, political and world views, goals, responsibilities, cognitive biases, attachment, age, gender and selected activities[7]. Social factors include religion, urban-rural differences, norms, social class, proximity to problematic environmental sites and cultural and ethnic variations. Robbins and Judge (2011: 172), said The Big Five Personality, a person can be seen in his tendency to have personality traits that are more important in one dimension than in the other four dimensions[8]. Colquitt, et.al (2011: 172) added that, the five dimensions of personality are conscientiousness, agreeableness, neuroticism, openness to experience, and extraversion[9].

\section{RESEARCH METODHOLOGY}

The research method used was a survey method with correlational techniques. This research is concerned with collecting data to determine whether there is a relationship between variables and how much strength the relationship has (correlation coefficient). This research was conducted at the Faculty of Engineering students, Budi Luhur University Architecture Study Program.

The target population (target population) of this study are all students of Budi Luhur University Jakarta. While the accessible population of research is students of the Faculty of Engineering, Budi Luhur University, Jakarta. The sampling technique in this study uses simple random sampling. Simple random sampling is a sample taken from a population by not picking out individuals who are members of the sample on the basis of certain reasons or reasons that are subjective. The number of samples taken is based on the formula put forward by Slovin (Sevilla et. Al., 2007: 182). Teknik analisis data adalah menggunakan uji regresi dan korelasi. Analisis data with descriptive statistics and inferential statistics. Previously performed the requirements analysis test, then followed the following stages: normality test using the Lilliefors test. Homogeneity test uses Bartlett test. To obtain the coefficient of determination of the independent variable for variation in the dependent variable is calculated by the second order correlation. The analysis program for processing data in research uses Microsoft Excel and SPSS software version 21.00 for Windows

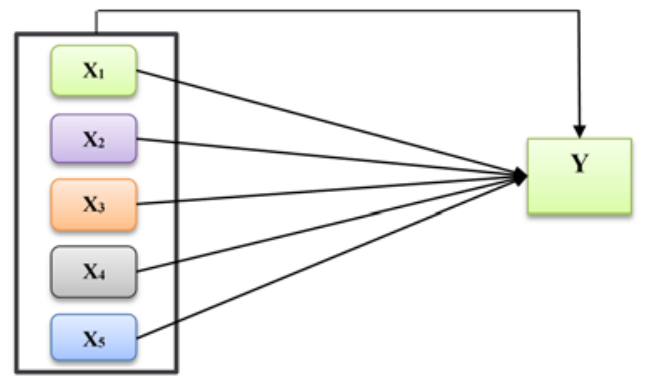

Keterangan :

$\mathrm{X}_{1}=$ Conscientiousness

$\mathrm{X}_{2}=$ Agreeableness

$\mathrm{X}_{3}=$ Neuroticism

$\mathrm{X}_{4}=$ Openness

$\mathrm{X}_{5}=$ Extraversion

$\mathrm{Y}=$ Behavior of environmental insights related to green architecture

Figure 1. Research design

(Source: Researcher, 2019)

\section{ANALYSIS AND DISCUSSION}

Instrument of environmental insight behavior variables related to green architecture arranged as many as 40 items. The item validity testing technique is done by determining the correlation coefficient between item scores and total scores. The reliability coefficient of environmental insight behavior instruments related to green architecture is calculated using the Alpha Cronbach formula as follows: a) The results of the reliability coefficient count for 30 people and 40 items, amounting to 0.917 . This means that it has a level of trust in the research instrument of $(0.917) 2 \times 100 \%=84.02 \%$. b) The results of calculating the reliability coefficient of 30 people and 35 valid items after dropping as many as 5 drops, amounting to 0.923 . This means that it has a level of trust in the research instrument of (0.923) 2 X 100\% $=85.19 \%$. 
The big five personality factor variable instruments are composed of 40 items. The item validity testing technique is done by determining the correlation coefficient between item scores and total scores. The determination uses the product moment correlation formula. Validity test is carried out at $\alpha=0.05$ and on rtable with $\mathrm{n}-2=30-2=28$ is 0.361 . If $\mathrm{r}$ count $>\mathrm{r}$ table, then the item is declared valid. And vice versa, if $\mathrm{r}$ count $<\mathrm{r}$ table then the item is declared fall (drop). The reliability coefficient of the big five personality factor instrument was calculated using the Cronbach Alpha formula as follows: a) The results of the reliability coefficient counted 30 people and 52 items, amounting to 0.907 . This means having a level of trust in research instruments

of $(0.907) 2 \mathrm{X} 100 \%=82.26 \%$. b) The results of the reliability coefficient counted as many as 30 people and 38 valid items after removing the drop items were 14 , amounting to 0.914 . This means that it has a level of trust in the research instrument of (0.914) 2 X $100 \%=83.54 \%$.

The data analysis technique is to use regression and correlation tests. analysis requirements, then followed the following steps: normality test using the Lilliefors test. Homogeneity test uses Bartlett test. To obtain the coefficient of determination of the independent variable for variation in the dependent variable is calculated by the second order correlation. The analysis program for processing data in research uses Microsoft Excel and SPSS software version 21.00 for Windows.

The analysis was conducted on Big Five Personality (conscientiousness, agreeableness, neuroticism, openness, and extraversion) that influence the behavior of environmental insights related to green architecture. The results of the analysis are summarized in the following table:

Table 1. Factors Affecting Environmental Insight Behavior Regarding Green Architecture

\begin{tabular}{|c|c|c|c|c|c|c|}
\hline \multirow{2}{*}{ No } & \multirow{2}{*}{$\begin{array}{l}\text { Analysis } \\
\text { Criteria }\end{array}$} & \multicolumn{5}{|c|}{$\begin{array}{c}\text { Factors Affecting Environmental Insight Behavior } \\
\text { Regarding Green Architecture }\end{array}$} \\
\hline & & $\mathrm{X}_{1}$ & $\mathbf{X}_{2}$ & $\mathbf{X}_{3}$ & $\mathrm{X}_{4}$ & $\mathbf{X}_{5}$ \\
\hline 1 & $\begin{array}{l}\text { Regression } \\
\text { Analysis }\end{array}$ & $\begin{array}{l}F_{\text {hitung }} 7,53> \\
F_{\text {tabel }} 3,34 \text { on } \alpha= \\
0,01\end{array}$ & $\begin{array}{l}F_{\text {hitung }} 6,08> \\
F_{\text {tabel }} 3,34 \text { on } \alpha= \\
0,01\end{array}$ & $\begin{array}{l}F_{\text {hitung }} 4,77> \\
F_{\text {tabel }} \alpha=0,05 \text { and } \\
0,01\end{array}$ & $\begin{array}{l}F_{\text {hitung }} 7,69> \\
F_{\text {tabel }} \alpha=0,05 \text { and } \\
0,01\end{array}$ & $\begin{array}{l}\mathrm{F}_{\text {hitung }} \\
5,69> \\
\mathrm{F}_{\text {tabel }} \alpha= \\
0,01\end{array}$ \\
\hline 2 & $\begin{array}{l}\text { Traffic } \\
\text { Testing }\end{array}$ & $\begin{array}{l}F_{\text {hitung }} \text { of } 0,92< \\
F_{\text {tabel }} \text { of } 1,95 \text { on } \\
\alpha=0,05\end{array}$ & $\begin{array}{l}F_{\text {hitung }} \text { of } 0,83< \\
F_{\text {tabel }} 1,85 \text { on } \alpha= \\
0,05\end{array}$ & $\begin{array}{l}\text { Fhitung of } 1,108 \\
<\text { Ftable } \alpha=0,05 \\
\text { and } 0,01\end{array}$ & $\begin{array}{l}F_{\text {hitung }} \text { of } 1,04< \\
F_{\text {tabel }} \alpha=0,05 \text { and } \\
0,01\end{array}$ & $\begin{array}{l}\mathrm{F}_{\text {hitung }} \text { of } \\
1,109< \\
\mathrm{F}_{\text {tabel }} \alpha= \\
0,05 \text { and } \\
0,01\end{array}$ \\
\hline 3 & $\begin{array}{l}\text { Correlation } \\
\text { coefficient }\end{array}$ & $\begin{array}{l}\mathrm{t}_{\text {hitung }}>\mathrm{t}_{\text {tabel }} \text { on } \alpha \\
=0,01 \text { or } 2,745 \\
>2,661\end{array}$ & $\begin{array}{l}t_{\text {hitung }}>t_{\text {tabel }} \text { on } \alpha \\
=0,05 \text { or } 2,467> \\
2,001\end{array}$ & $\begin{array}{l}t_{\text {hitung }}>t_{\text {tabel }} \alpha= \\
0,05 \text { or } 2,184> \\
2,001\end{array}$ & $\begin{array}{l}t_{\text {hitung }}>t_{\text {tabel }} \alpha= \\
0,01 \text { or } 2,773> \\
2,661\end{array}$ & $\begin{array}{l}\mathrm{t}_{\text {hitung }}> \\
\mathrm{t}_{\text {tabel }} \alpha= \\
0,05 \text { or } \\
2,386> \\
2,001\end{array}$ \\
\hline 4 & $\begin{array}{l}\text { Coefficient of } \\
\text { Determination }\end{array}$ & $\begin{array}{l}0,107 \times 100 \% \\
\text { means } 10,7 \% \\
\text { variation }\end{array}$ & $\begin{array}{l}0,088 \times 100 \% \\
\text { means } 8,8 \% \\
\text { variation }\end{array}$ & $\begin{array}{l}0,070 \times 100 \% \\
\text { means } 7 \% \\
\text { variation }\end{array}$ & $\begin{array}{l}0,109 \times 100 \% \\
\text { means } 10,9 \% \\
\text { variation }\end{array}$ & $\begin{array}{l}0,083 \times \\
100 \% \\
\text { means } \\
8,3 \% \\
\text { variation } \\
\end{array}$ \\
\hline 5 & $\begin{array}{l}\text { Analysis } \\
\text { Results }\end{array}$ & $\begin{array}{l}\text { The relationship } \\
\text { between } \\
\text { conscientiousnes } \\
\mathrm{s} \text { and } \\
\text { environmental } \\
\text { insight related to } \\
\text { green } \\
\text { architecture, if } \\
\text { agreeableness, } \\
\text { neuroticism, } \\
\text { openness, and } \\
\text { extraversion are } \\
\text { controlled to } \\
\text { produce a } \\
\text { coefficient of } \\
\text { ry } 1.2345=\end{array}$ & $\begin{array}{l}\text { The relationship } \\
\text { between } \\
\text { agreeableness } \\
\text { with } \\
\text { environmental } \\
\text { insight behavior } \\
\text { related to green } \\
\text { architecture, if } \\
\text { conscientiousnes } \\
\text { s, neuroticism, } \\
\text { openness, and } \\
\text { extraversion are } \\
\text { controlled to } \\
\text { produce } \\
\text { coefficient } \\
\text { ry2.1345 = } 0.20 \text {. }\end{array}$ & $\begin{array}{l}\text { The relationship } \\
\text { between } \\
\text { neuroticism and } \\
\text { environmental } \\
\text { insight behavior } \\
\text { related to green } \\
\text { architecture, if } \\
\text { conscientiousnes } \\
\text { s, agreeableness, } \\
\text { openness, and } \\
\text { extraversion are } \\
\text { controlled the } \\
\text { result is the } \\
\text { coefficient } \\
\text { ry3.1245 = } 0.23 \text {. } \\
\text { This means that }\end{array}$ & $\begin{array}{l}\text { The relationship } \\
\text { between } \\
\text { openness and } \\
\text { environmental } \\
\text { insight behavior } \\
\text { related to green } \\
\text { architecture, if } \\
\text { conscientiousnes } \\
\text { s, agreeableness, } \\
\text { neuroticism, and } \\
\text { extraversion are } \\
\text { controlled the } \\
\text { result is the } \\
\text { coefficient } \\
\text { ry4.1235 = } \\
0.120 . \text { This }\end{array}$ & $\begin{array}{l}\text { The } \\
\text { relations } \\
\text { hip } \\
\text { between } \\
\text { extravers } \\
\text { ion and } \\
\text { environm } \\
\text { ental } \\
\text { insight } \\
\text { behavior } \\
\text { related to } \\
\text { green } \\
\text { architect } \\
\text { ure, if } \\
\text { conscient } \\
\text { iousness, }\end{array}$ \\
\hline
\end{tabular}




\begin{tabular}{|c|c|c|c|c|c|c|}
\hline & & $\begin{array}{l}0.169 . \text { This } \\
\text { means that even } \\
\text { though } \\
\text { agreeableness, } \\
\text { neuroticism, } \\
\text { openness, and } \\
\text { extraversion are } \\
\text { controlled from } \\
\text { the relationship } \\
\text { between } \\
\text { conscientiousnes } \\
\text { s and } \\
\text { environmental } \\
\text { insight related to } \\
\text { green } \\
\text { architecture, it } \\
\text { remains positive } \\
\text { and very } \\
\text { significant. }\end{array}$ & $\begin{array}{l}\text { This means that } \\
\text { although } \\
\text { conscientiousnes } \\
\text { s, neuroticism, } \\
\text { openness, and } \\
\text { extraversion are } \\
\text { controlled from } \\
\text { the relationship } \\
\text { between } \\
\text { agreeableness } \\
\text { with } \\
\text { environmental } \\
\text { insight related to } \\
\text { green } \\
\text { architecture, it } \\
\text { remains positive } \\
\text { and significant }\end{array}$ & $\begin{array}{l}\text { although } \\
\text { conscientiousnes } \\
\text { s, agreeableness, } \\
\text { openness, and } \\
\text { extraversion are } \\
\text { controlled from } \\
\text { the relationship } \\
\text { between } \\
\text { neuroticism and } \\
\text { environmental } \\
\text { insight related to } \\
\text { green } \\
\text { architecture, it } \\
\text { remains positive } \\
\text { and significant }\end{array}$ & $\begin{array}{l}\text { means that } \\
\text { although } \\
\text { conscientiousnes } \\
\text { s, agreeableness, } \\
\text { neuroticism, and } \\
\text { extraversion are } \\
\text { controlled from } \\
\text { the relationship } \\
\text { between } \\
\text { openness and } \\
\text { environmental } \\
\text { insight related to } \\
\text { green } \\
\text { architecture, it } \\
\text { remains positive } \\
\text { and significant. }\end{array}$ & $\begin{array}{l}\text { agreeable } \\
\text { ness, } \\
\text { neurotici } \\
\text { sm, and } \\
\text { openness } \\
\text { are } \\
\text { controlle } \\
\mathrm{d} \text { the } \\
\text { result is } \\
\text { the } \\
\text { coefficie } \\
\text { nt } \\
\text { ry5.1234 } \\
=0.025 . \\
\text { This } \\
\text { means } \\
\text { that } \\
\text { although } \\
\text { conscient } \\
\text { iousness, } \\
\text { agreeable } \\
\text { ness, } \\
\text { neurotici } \\
\text { sm, and } \\
\text { openness } \\
\text { are } \\
\text { controlle } \\
\text { d from } \\
\text { the } \\
\text { relations } \\
\text { hip } \\
\text { between } \\
\text { extravers } \\
\text { ion and } \\
\text { environm } \\
\text { ental } \\
\text { insight } \\
\text { related to } \\
\text { green } \\
\text { architect } \\
\text { ure, it } \\
\text { remains } \\
\text { positive } \\
\text { and } \\
\text { significa } \\
\text { nt }\end{array}$ \\
\hline 6 & $\begin{array}{l}\text { Implementatio } \\
\mathrm{n}\end{array}$ & \multicolumn{5}{|c|}{$\begin{array}{l}\text { Implementation of Environmental Insight Behavior Strategy Related to Green } \\
\text { Architecture in order to create a high environmental commitment and involve all students } \\
\text { in addressing environmental issues that occur and guide students to work together to } \\
\text { make positive contributions to the successful implementation of strategies for the } \\
\text { sustainability of the campus environment. So In the End Can Be Created Environmental } \\
\text { Insight Behavior Relating to Green Architecture. }\end{array}$} \\
\hline
\end{tabular}

Source: Researcher Analysis Results, 2019

Information :

$\mathrm{X}_{1}=$ Conscientiousness

$\mathrm{X}_{2}=$ Agreeableness

$\mathrm{X}_{3}=$ Neuroticism

$\mathrm{X}_{4}=$ Openness

$\mathrm{X}_{5}=$ Extraversion

$\mathrm{Y}=$ Behavior of environmental insights related to green architecture 


\section{THE RELATIONSHIP BETWEEN THE BIG FIVE PERSONALITY FACTOR TOGETHER WITH ENVIRONMENTAL INSIGHT RELATED TO GREEN ARCHITECTURE}

The relationship between the big five personality factors (conscientiousness, agreeableness, neuroticism, openness and extraversion) together with environmental insight related to green architecture is analyzed by multiple regression. The results of the analysis get the equation $\hat{Y}=88.290+1.133 \mathrm{X} 1+0.131 \mathrm{X} 2+0.132 \mathrm{X} 3+$ $1,191 \mathrm{X} 4+0.212 \mathrm{X} 5$. In the table above the results of testing the significance of the regression coefficient as a whole or plural namely Fcount $8.903>\mathrm{F}$ table $\alpha=0.05$ and 0.01 , then the regression equation is very significant. Analysis of multiple correlations between the big five personality factor (conscientiousness, agreeableness, neuroticism, openness and extraversion) together with environmental insight behavior related to green architecture yields multiple correlation coefficients (Ry12345) of 0.352. T test results for tcount $>\mathrm{t}$ table $\alpha=0.01$ or $2.984>2.661$. The results of the study are that there is a very significant positive relationship between the big five personality factors (conscientiousness, agreeableness, neuroticism, openness and extraversion) together with environmental insight related to green architecture. This means that the better the big five personality factors (conscientiousness, agreeableness, neuroticism, openness and extraversion), the better the behavior of environmental insight related to green architecture.

The coefficient of determination of the relationship between the big five personality factor (conscientiousness, agreeableness, neuroticism, openness and extraversion) together with environmental insight related to green architecture, in the second order correlation of $0.124 \times 100 \%$ means $12.4 \%$. This shows that $12.4 \%$ of the variation in environmental insight related to green architecture can be explained by the big five personality factors (conscientiousness, agreeableness, neuroticism, openness and extraversion) together. It can also be interpreted as a directly proportional relationship between the big five personality factors (conscientiousness, agreeableness, neuroticism, openness and extraversion) together with environmental insight related to green architecture by 0.352 through a regression model $\hat{\mathrm{Y}}=88.290+1.133 \mathrm{X} 1+0.131 \mathrm{X} 2+0.132 \mathrm{X} 3+1,191 \mathrm{X} 4+$ $0,212 X 5$.

The results of testing the six hypotheses proposed in this study concluded that all research hypotheses submitted in chapter II were accepted, meaning that environmental insight related to green architecture by $12.4 \%$ could be clarified by the big five personality factor (conscientiousness, agreeableness, neuroticism, openness and extraversion).

\section{CONCLUSION}

Based on these findings it can be concluded, if you want to improve the behavior of environmental insights related to green architecture, then the big five personality factor (conscientiousness, agreeableness, neuroticism, openness and extraversion) also need to be improved. recommendations for Budi Luhur university Need to consider conscientiousness, agreeableness, neuroticism, openness and extraversion as factors that influence insight behavior environment related to green architecture in every decision-making and planning campus activities.

\section{Acknowledgements}

Thank you to the Director of Research and Community Service for providing the opportunity and funding for this research and all those who have assisted in the completion of this research.

\section{Reference}

[1] K. Goh and W. CH, "Gastrooesophageal reflux disease: An Emerging Disease in Asia," Gastroenterol Hepatol, vol. 2, pp. 118-123, 2006.

[2] Sawitria, D. R., H. Hadiyanto, and S. P, "Pro-Environmental Behavior from a Social Cognitive Theory Perspective," in International Conference on Tropical and Coastal Region Eco-Development 2014(ICTCRED 2014), 2015, pp. 27-33.

[3] T. H. Karyono, Green Architecture: Introduction to Understanding Green Architecture in Indonesia. Jakarta: PT Raja Grafindo Persada, 2010.

[4] Robertson, J. L, and J. Barling, "Greening organizations through leaders' influence on employees' proenvironmental behaviors," J. Organ. Behav., vol. 34, pp. 176-194, 2013.

[5] Chamorro-Premuzic, T. Swami, V., R. Snelgar, and Furnham, “A. Egoistic, altruistic, and biospheric environmental concerns: A path analytic investigation of their determinants," Scand. J. Psychol., vol. 51, pp. 139-145, 2015.

[6] Y. Liao, S. S. Ho, and X. Yang, "Motivators of Pro-Environmental Behavior: Examining the Underlying Processes in the Influence of Presumed Media Influence Model," Sci. Commun., vol. 38, no. 1, pp. 51- 
73, 2016.

[7] R. Gifford and A. Nilsson, "Personal and social factors that influence pro-environmental concern and behavior," Int. J. Psychol., pp. 1-17, 2014.

[8] S. P. Robbins and T. A. Judge, Organizational Behavior. New Jersey: Pearson Education Inc, 2011.

[9] et. a. Colquitt, A Pason, Organizational Behavior, Improving Performance and Commitment in the Workplace. New York: MacGraw Hill, 2011. 